\title{
ПРАВОВА ПРИРОДА БУДАПЕШТСЬКОГО МЕМОРАНДУМУ ТА ВАГА ПРОПИСАНИХ ГАРАНТІЙ
}

\author{
ГОЛОВІНА Вікторія Анатоліївна - студентка господарсько-правового \\ факультету Національного юридичного університету імені Ярослава Мудрого \\ м. Харкова. \\ ГОРДІЕНКО Світлана Костянтинівна - студентка господарсько-правового \\ факультету Національного юридичного університету імені Ярослава Мудрого \\ м. Харкова.
}

DOI 10.32782/EP.2020.3.23

У статті розкривається актуальне наразі питання шьодо правової природи Будапештсъкого меморандуму. Досліджуються питання змісту изього документа, виконання зазначених гарантій та наслідки його порушення. Аналіз положень здійснюеться через різні точки зору науковців та політиків. При иъому висвітлюються декілька способів розв'язання проблеми недотримання взятих на себе зобов'язань країнами-гарантами.

Ключові слова: Будапештсъкий меморандум, договір, зобов'язання, держави-гаранти, територіальна цілісність, ядерне роззброєння, санкиї.

\section{Вступ}

Під час останніх місцевих виборів 25 жовтня 2020 р. українцям було запропоновано відповісти на декілька запитань від Президента України. Одним з них було: чи підтримуєте ви право України на використання гарантій безпеки, визначених Будапештським меморандумом, для відновлення iii державного суверенітету і територіальної цілісності? Водночас Володимир Зеленський не викрив свою стратегію щодо наступних дій стосовно цього питання, проте наголосив, що наразі необхідно зафіксувати волю народу, щоб отримати політичний мандат з метою подальшого вибудовування державної позиції. Зі слів Президента: «Україна в Європі повинна бути дуже сильною, наш флот повинен бути дуже міцним ... Ми говоримо про те, що всі зобов'язані виконувати свої домовленості».
Мета і завдання дослідження

Діяльність нашого Президента підтверджує актуальність питання щодо додержання гарантій, наданих Будапештським меморандумом? і саме тому $є$ необхідним розкрити сутність його правової природи та віднайти шляхи вирішення порушень цього договору в сучасних умовах.

\section{Виклад основного матеріалу}

Після розпаду СРСР Україна успадкувала третій за потужністю, після Росії та СІІА, арсенал ядерної зброї у світі. Однак у січні 1994 року вона підтвердила своє прагнення до повного ядерного роззброєння у Тристоронній заяві президентів України, РФ і СШІА. І в цьому ж році Україна приєдналася до Договору про нерозповсюдження ядерної зброї як без'ядерна держава та остаточно звільнилася від ядерного потенціалу в 1996-му, передавши свої ядерні боєголовки в Росію для ліквідації [1, с. 10].

5 грудня 1994 року в Будапешті між Україною ( $\curlywedge$. Кучма), Російською Федерацією (Б. Єльцин), Сполученим Королівством Великої Британії та Північної Ірландії (Дж. Мейджор) та Сполученими Штатами Америки (У. Клінтон) був укладений Меморандум про гарантії безпеки у зв'язку з приєднанням України до Договору про нерозповсюдження ядерної зброї, який з моменту підписання набув чинності. Слід зазначити, що дві інші ядерні держави та постійні члени Ради Безпеки ООН - Китай і Франція - офіційно 
висловили аналогічні гарантії Україні у формі дипломатичних нот (Заява Уряду КНР від 04.12.1994 і Декларація Франції із супровідним листом Президента Ф. Міттерана від 05.12.1994), хоча формально й не підписували Будапештський меморандум.

Будапештський меморандум містить шість зобов'язань США, Сполученого Королівства і РФ стосовно України: поважати незалежність, суверенітет та наявні кордони України; утримуватися від погрози силою або ï застосування проти України, крім як 3 метою самооборони або в якийсь інший спосіб відповідно до Статуту ООН; утримуватися від економічного примусу, спрямованого на те, щоб підпорядкувати своїм власним інтересам здійснення Україною прав, притаманних іiі суверенітету, і в такий спосіб забезпечити собі переваги будьякого роду; домагатися негайних дій Ради Безпеки ООН із надання допомоги Україні як державі - учасниці Договору про нерозповсюдження ядерної зброї, що не володіє ядерною зброєю, у випадку якщо Україна стане жертвою акту агресії або об'єктом агресії із застосуванням ядерної зброї; не застосовувати ядерну зброю проти неядерних держав? крім випадків нападу таких держав на ядерну державу в союзі з іншою ядерною державою; проводити консультації у випадку виникнення ситуацій, внаслідок яких постає питання стосовно цих зобов'язань [2].

Росія ж виконала тільки п'ятий пункт Меморандуму, не враховуючи універсального шостого. Вона дійсно не застосовувала проти України ядерної зброї, але, у свою чергу, перші чотири пункти грубо порушила.

Про те, що РФ не збирається дотримуватися своїх зобов'язань поважати територіальну цілісність і непорушність кордонів України, стало зрозумілим ще наприкінці 2003 року - у зв'язку з подіями, пов'язаними 3 українською косою Тузла в Керченській протоці, що загрожувало територіальній цілісності України [3, с. 157]. На той час світ не відреагував належним чином на такі порушення зобов'язань одним s3 гарантів Меморандуму, які наростали роками, що в підсумку призвели до наслідків, очевидцями яких ми є сьогодні - застосування сили проти України. Надалі, так звані «газові ві- йни» стали проявом свідомого економічного тиску, який спрямовувався на те, щоб підкорити власним інтересам Україну. Також слід зазначити, що США та Велика Британія домагалися негайних дій Ради Безпеки $\mathrm{OOH}$, які блокувала Росія, використовуючи право вето, із чого випливає необхідність реформувати використання права вето постійними членами Ради Безпеки ООН.

Окрім грубого порушення Росією Будапештського меморандуму, фактично не дотримались своїх зобов'язань та не захистили від зовнішньої агресії Україну й інші країнигаранти, а це - США та Велика Британія, але слід враховувати також Францію та Китай. Звичайно, Сполучені Штати можна вважати найбільшим захисником України, але все одно - це не те, що гарантувалося. Китай же утримався під час голосування стосовно анексії Криму в ГА ООН у березні 2014 року, а окремі французькі депутати навіть поїхали на окупований півострів [4].

На сьогодні у науці виникають дискусії стосовно правової природи Будапештського меморандуму. Зокрема, К. Гурін наводить докази, що Будапештський меморандум є політичною домовленістю [5, с.187]. Олена Святун та Олексій Святун розглядають Меморандум як політичну угоду [6, c.18]. Близькою до зазначених позицій $є$ оцінка В. Гусарова, який вважає Меморандум дипломатичним документом [7]. Нещодавно свою думку з цього приводу висловила посол Германії Анка Фельдхузен: «Будапештський меморандум - це політична декларація і не більше, це не міжнародний договір ... тобто отримати ці гарантії сьогодні просто неможливо» [8]. Проте, ми підтримуємо загальну, найбільш висвітлену серед науковців думку, які обгрунтовують свою позицію тим, що відповідно доп. а ч. 1 ст. 2 Віденської конвенції про право міжнародних договорів 1969 р. «договір» - це міжнародна угода, укладена між державами в письмовій формі та регульована міжнародним правом, незалежно від того, чи викладена така угода в одному документі, двох чи кількох зв'язаних між собою документах, а також незалежно від їі конкретного найменування [9]. Таким чином, Будапештський меморандум відповідає всім 
критеріям міжнародного договору, визначеним у понятті Конвенції.

Слід зазначити, що стаття 26 Віденської конвенції про право міжнародних договоpiв 1969 р. встановлюе принцип pacta sunt servanda, що значить - кожен чинний договір $є$ обов'язковим для його учасників і повинен добросовісно виконуватись, а його порушення є недотриманням імперативної норми јus cogens [10].

Російська Федерація намагалась обгрунтувати недійсність Меморандуму, посилаючись на статтю 15 Федерального закону про міжнародні договори РФ від 16 червня 1995 року, у якій вказується про необхідність ратифікації міжнародних договорів Росії з питань роззброєння чи міжнародного контролю над озброєннями, забезпечення міжнародного миру та безпеки [11]. Слід зазначити, що Будапештський меморандум був підписаний раніше, ніж цей закон набув чинності, а тому зазначена норма на нього не поширюється. Доречним буде згадати статтю 27 Віденської конвенції про право міжнародних договорів 1969 р., згідно з якою «учасник не може посилатися на положення свого внутрішнього права в якості виправдання для невиконання ним договору» [9].

Крім того, відповідно до російського Федерального закону про міжнародні договори, а також згідно 3 Віденською конвенцією про право міжнародних договорів, «ратифікація є лише одним із багатьох способів надання згоди на обов'язковість виконання міжнародного договору» [9]. Тобто якщо в документі зазначено, що він набуває чинності з моменту його підписання, то він не потребує жодної іншої згоди на свою обов'язковість [4].

Зазначимо, що важливим міжнародно-правовим підтвердженням чинності та обов'язковості для виконання сторонами Будапештського меморандуму також є те, що він зафіксований в офіційних документах Генасамблеї та Радбезу ООН, а також постійної Конференції ООН із роззброєння [4].

Про певну слабкість гарантій, які було надано Україні ядерними державами, свідчить те, що в англомовному тексті Меморандуму (в його назві) було використано термін «security assurances» (безпекові запевнення), що є слабшим за термін «security guarantees» (безпекові гарантії). Варто зауважити, що в російськомовному тексті Меморандуму, як і в україномовному, використовується термін «гарантии безопасности» [12, с.8].

«Якщо Будапештський меморандум не є тим документом, що надає Україні гарантії безпеки, тобто є «юридично нікчемним», як заявляють деякі російські політики та експерти, то це значило б, що Україна не є стороною ДНЯЗ як неядерна країна і має право на власну ядерну зброю», - підкреслив заступник Постійного представника України при міжнародних організаціях Ігор Аоссовський під час дискусії, організованої у Дипакадемії Відня австрійською громадською організацією Unlimited Democracy 3 приводу 25-ї річниці Будапештського меморандуму [4].

Звертаючи увагу на наслідки порушення Будапештського меморандуму, варто зазначити, що вони не вказані в самому договорі, а тому необхідно керуватися загальними нормами. Згідно зі статтею 60 Віденської конвенції про право міжнародних договорів 1969 р. якщо одна сторона порушує положення договору, то інші сторони мають право: зупинити чи припинити дію договору в цілому або в частині у відносинах між собою i державою, яка порушила договір, або у відносинах між усіма учасниками (іншим учасникам за угодою, досягнутою одноголосно); посилатись на це порушення як на підставу зупинення дії договору в цілому або в частині у відносинах між ним і державою, яка порушила договір (учасникові, який особливо постраждав у результаті порушення); посилатись на це порушення як на підставу для зупинення дії договору в цілому або в частині щодо самого себе, якщо договір має такий характер, що істотне порушення його положень одним учасником докорінно змінює становище кожного учасника щодо подальшого виконання ним своїх зобов'язань, які випливають 3 договору (будь-якому іншому учасникові, крім держави, яка порушила договір) [9].

Продовжуючи тему наслідків, логічним було б згадати про санкції за недотримання Будапештського меморандуму, але його 


\section{Міжнародне право}

змістом вони також не визначені. Аеонід Кравчук зазначав: «Механізм санкцій у разі порушення не прописали». На це ж вказують і такі німецькі експерти, як Гергард Сiмон 3 Кельнського університету у розмові 3 DW: «Там ніде не написано, що у разі порушення цього меморандуму однією державою решта застосують військову силу». Схоже оцінює ситуацію і німецький публіцист, експерт з питань України Вінфрід ШнайдерДетерс: «Угода не варта паперу, на якому вона написана» [13].

Існує дві можливості розв'язання проблем, пов'язаних з порушенням Будапештського меморандуму, які дуже складно, але можна з нього виокремити. Перша - домогтися посилення міжнародних зобов'язань у зв'язку з відмовою в 1990-х від ядерної зброї, друга - «покарати» ядерні держави, які порушили Меморандум відмовою від узятих на себе в рамках ДНЯЗ зобов’язань. Обидві можливості обмежені міркуваннями політичного реалізму [14].

Чимало експертів схиляються до думки, що одним із форматів реалізації безпекових гарантій Україні в рамках Будапештського меморандуму могло б стати розширення кола офіційних учасників нинішнього мирного процесу (Україна, Франція, Німеччина та Росія) шляхом включення інших впливових країн, гарантів Меморандуму - США, Великої Британії та, певним чином, Китаю. Зрозуміло, що такі спроби зустрінуть різке несприйняття, передусім, РФ, однак такий формат міг би стати ефективнішим у врегулюванні ситуації на окупованих територіях України [4].

Ще однією цікавою думкою є слова колишнього міністра закордонних справ України Володимира Огризко: «Ми, як Україна, маємо лише два варіанти. Або бути дуже сильною країною у військовій сфері, або друга опція - вступ до НАТО. Я надаю перевагу обом варіантам» [4].

Про підписаний Меморандум не можна забувати i робити кроки, що його знецінюють. Україна має право висунути юридичні претензії Росії у зв’язку з його порушенням. I це має бути зроблено у відповідній формі у відповідний час. Зусил- ля мають бути спрямовані на юридичні дії, а не на марне політичне прожектерство [14].

Часто можна почути, що хоча Будапештський меморандум i надає певні «віртуальні» гарантії Україні, вони не 6 конкретно визначеними. Але ж у більшості інших міжнародно-правових документах такі гарантії теж не прописано детально. Яскравим прикладом, на нашу думку, може бути Північноатлантичний (Вашингтонський) договір 1949 року, який справедливо вважають чи не найбільш зобов'язальним та обов'язковим для виконання його сторонами. У славнозвісній статті 5 цього Договору йдеться про таке: «Сторони домовилися, що збройний напад проти однієї чи більше сторін... буде нападом проти всіх i, відповідно... кожна зі сторін... надаватиме допомогу сторонам, що зазнали нападу, шляхом ужиття негайних необхідних індивідуальних і колективних заходів, включно з використанням збройної сили, для відновлення та забезпечення безпеки в регіоні» [15]. Як бачимо, навіть у цьому «класичному» прикладі зобов'язального документа в міжнародному праві зобов'язання та гарантії сторін прописано не досить конкретно й однозначно. На нашу думку, такою $є$ загальноприйнята світова практика міжнародних договорів. Лише в юридичних документах вузьких розділів права, зокрема таких, як корпоративне право, можна знайти приклади детально прописаних зобов’ язань і конкретних дій сторін, а також відповідних санкцій за невиконання цих зобов’ язань [1, с. 29].

Три ядерні держави і дві, що окремо приєдналися до них за допомогою односторонніх актів, зобов'язалися поважати суверенітет, утримуватися від погроз і домагатися певних дій щодо України. Вони не зобов'язувалися вважати напад на Україну нападом на себе, подібно до того, як зазначено в Північноатлантичному договорі, що лежить в основі НАТО. Однак міжнародноправовий статус у них однаковий, і обидва документи є договорами. Просто сторони домовилися про різне і, відповідно, мають виконувати саме те, про що домовилися [14].

На нашу думку, необхідно враховувати, що не втрачає своєї актуальності завдання 
3 нерозповсюдження ядерної зброї та створення нових міжнародних документів, які 6 гарантували безпеку державам у разі повної відмови або намірів з виробництва ядерної зброї й саме тому положення Будапештського меморандуму потребують актуалізації.

Провал наявних у Меморандумі гарантій негативно впливатиме на переговорні процеси з урегулювання сучасних світових проблем нерозповсюдження, серед яких найбільш резонансними насамперед $\epsilon$ північнокорейська та іранська ядерні проблеми $[16$, с.46].

\section{Висновок}

У статті було досліджено актуальну проблему стосовно правової природи Будапештського меморандуму. Визначено, що цей документ $\epsilon$ міжнародним договором. Розглянуто різноманітну аргументацію недійсності цього акту зі сторони країн-гарантів та наведені докази того, що положень Меморандуму необхідно дотримуватися. Виділено проблему необхідного впровадження в життя механізму застосування санкцій за порушення цього договору та наведено декілька варіантів вирішення нинішньої ситуації в Україні.

\section{Література}

1. Аоссовський I. Є. Міжнародно-правовий статус Будапештського меморандуму: договір, обов'язковий для виконання всіма його сторонами : монографія. Київ : Генеральна дирекція 3 обслуговування іноземних представництв, 2015. 123 с.

2. Меморандум про гарантії безпеки у зв'язку з приєднанням України до Договору про нерозповсюдження ядерної зброї (Будапештський меморандум). https://zakon. rada.gov.ua/laws/show/998 158\#Text (дата звернення: 02.11.2020).

3. Травников А. Коса Тузла и стратегические интересы России. - Ростов-на-Дону: Феник, 2005. 268 с.

4. Короткий В. Будапештський меморандум. «Нікчемний» чи все ж впливовий? Укрінформ: Мультимедійна платборма іномовлення в Украӥні. URL: https://tinyurl.com/ y3uhbvbh (дата звернення: 02.11.2020).
5. Гурін К. Будапештський меморандум 1994р.: договір чи домовленість? /К. Гурін // Публічне право : наук.-практ. юрид. журн. - 2016. - №2 (22). - С. 182-188.

6. Святун О. Будапештський меморандум та його співвідношення 3 Договором про нерозповсюдження ядерної зброї /О. Святун, О. Святун // Віче: журн. Верховної Ради України. - К. : Держ. вид-во «Преса України», 2014. - № 20. - С.15-20.

7. Гусаров В. Нереалізований Будапештський меморандум і нові світові загрози / В. Гусаров. URL: https://tinyurl.com/ y2dhmxgz (дата звернення: 05.11.2020).

8. Сировой M. Аіга. Новини. URL: https://tinyurl.com/y3legtpc (дата звернення: 03.11.2020).

9. Віденська конвенція про право міжнародних договорів. URL: https://zakon. rada.gov.ua/laws/show/995 118\#Text (дата звернення: 03.11.2020).

10. Правова природа Будапештського меморандуму та наслідки його порушення Російською Федерацією. Украйнсъке право. URL: https://tinyurl.com/yxw5ds46 (дата звернення: 04.11.2020).

11. Федеральный закон «О международных договорах Российской Федерации» от 15.07.1995p. URL: http://www.rg.ru/1995/07/21/ mejdunarodnye-dogovorydok.html (дата звернення: 04.11.2020).

12. Аоссовський I.Є. До 20-ї річниці будапештських «гарантій»: Агресія Росії проти України як фактор ерозії міжнародноправових режимів нерозповсюдження. Зовнішні справи. 2014. № 11. С. 6-11.

13. Гончаренко Р., Каневський Д. Будапештський меморандум: що насправді обіцяли Україні? Deutsche Welle. URL: https://p. dw.com/p/1Dzdl (дата звернення: 05.11.2020).

14. Їжак О. Меморандум про вічні цінності. Зеркало недели. Украина. 2019. № 19. URL: https://tinyurl.com/y4rdudfz (дата звернення: 02.11.2020).

15. The North Atlantic Treaty. Washington D.C. 4 April 1949 URL: https://zakon.rada.gov. ua/laws/show/950 008\#Text (дата звернення: 05.11.2020).

16. Аоссовський I.Є. Історія, сучасний стан і перспективи корейського врегулювання. Зовнішні справи. № 4. 2014. С. 44-49. 


\section{АНОТАЦІЯ}

Будапештсъкий меморандум, попри його неоднозначне тлумачення з боку юристівміжнародників, політиків, дипломатів, залишається чи не єдиним політико-правовим документом, який Украйна на початку незалежності змогла укласти в обмін на добровільну відмову від третього у світі ядерного потениіалу, успадкованого після розпаду СРСР. 3 огляду на актуалізацію изього питання діяльністю нашого Президента постала необхідність його детального висвітлення.

Розглянутий історичний аспект укладення Будапештсъкого меморандуму, його значення у сучасному розвитку нашої держави. Проаналізовано кожен пункт Меморандуму на предмет порушення зобов'язань державами-гарантами. Проведений порівняльний аналіз декількох думок науковців та політиків стосовно правової природи Меморандуму та зроблений висновок, що він, безумовно, $е$ міжнародним договором відповідно до положень Віденсъкої конвениї про право міжнародних договорів 1969 р., отже, його необхідно дотримуватися, гарантї, які були надані, повинні виконуватися. При иъому наголошується на неправосильній аргументащії недійсності підписаного договору з боку Російської Федераиї та невиправдане використання на свою користь ситуацї̈ з перекладом обіиійної назви Будапештсъкого меморандуму іншими державами-учасницями.

Попри відсутність у самому тексті Меморандуму наслідків його порушення та механізму застосування санкиій виокремлено декілька шляхів можливого врегулювання згаданої проблеми в нинішній ситуащї, які запропоновані бахівиями з иъого питання.

Дане дослідження є корисним 3 тієї позииї, що розв'язання проблем, пов'язаних з дотриманням Будапештського меморандуму, які постали перед Украӥною - однозначно стане яскравим прикладом механізму дї щодо захисту своӥх інтересів та каталізатором подальшого ядерного роззброєння як досвіду дотримання світової безпеки.

\section{SUMMARY}

The Budapest Memorandum, despite its ambiguous interpretation by international lawyers, politicians, and diplomats, remains almost the only political and legal document that Ukraine was able to conclude at the beginning of independence in exchange for voluntarily renouncing the world's third nuclear capability inherited after the collapse of the Soviet Union. Given the actualization of this issue by the activities of our President, there is a need for its detailed coverage.

The historical aspect of the conclusion of the Budapest Memorandum, its significance in the modern development of our state is considered. Each item of the Memorandum was analyzed for breach of obligations by the guarantor states. A comparative analysis of several opinions of scholars and politicians regarding the legal nature of the Memorandum and concluded that it is definitely an international treaty in accordance with the provisions of the Vienna Convention on the Law of Treaties of 1969, so it must be complied with, guarantees provided must be fulfilled. At the same time, emphasis is placed on the invalid argumentation of the invalidity of the signed agreement by the Russian Federation and the unjustified use in their favor of the situation with the translation of the official name of the Budapest Memorandum by other member states.

Despite the absence in the text of the Memorandum of the consequences of its violation and the mechanism of application of sanctions, several ways of possible settlement of this problem in the current situation, which are proposed by experts on this issue.

This study is useful in that resolving Ukraine's compliance with the Budapest Memorandum will be a clear example of a mechanism to protect its interests and a catalyst for further nuclear disarmament as an experience of global security. 